\title{
Spirituality to Increase Entrepreneur's Satisfaction and Performance: The Islamic Perspective
}

\author{
Rizki Febriani \\ University of Muhammadiyah Malang
}

\begin{abstract}
This study purpose is to analyze the role of spirituality to improve the Islamic job satisfaction and Muslim entrepreneur performance. Total 158 questionnaires were distributed to the entrepreneurs of Muslim Community Malang, East Java, Indonesia. The data is analyzed by using Smart-PLS and Sobel test. The results show that spirituality is proven to increase the entrepreneurship satisfaction and performance. The business implication of this study is the entrepreneur should use the Islamic spirituality value to their work.
\end{abstract}

Keywords: Spirituality, Islamic Job Satisfaction, Islamic Performance

DOI: $10.7176 / \mathrm{EJBM} / 12-6-08$

Publication date: February $29^{\text {th }} 2020$

\section{INTRODUCTION}

Background

Islam is a perfect religion to gives guidance to people on how to run a business and how people should manage their working relationships with others to provide good benefits for common good to create prosperity for all people. Rasulullah SAW was a trader and he praised and prayed for honest traders in trading. This proves that trading is a noble profession in Islam.

Islam is an important foundation in life of a Muslim throughout the world. Some researchers argue that Islam also affects on organizational management practice of a Muslim, usually called management from an Islamic perspective (Khalid and Fontaine, 2011). Al-Qaradawi (2001) stated that revival of Islam is a real phenomenon that can be recognized through three signs: first, an increase in number of people who pray at mosque, especially young people; second, the spread of headscarves among women; and third, increasing sales of religious books. In addition, he suggested that motive behind this phenomena was the people desire to return to Allah by obeying Islamic teachings. Therefore, it can be assumed that they want to learn more about religion. This trend is also clear in business environment as concepts and problems of spirituality and religiosity in workplace are revealed more frequently.

Kouzes and Posner (2012) revealed that organizations and their leaders, who seek a higher meaning and purpose, have brought spirituality, religion, and faith into the business world. Kazmi (2004) stated that higher interest in spirituality and religion has been present in company managers. Islam is a completely inclusive way of life to speak all aspects of life through a complete socio-economic system (Khraim etc., 2011). These instructions are institutionalized in two main sources of his teachings, Koran and Hadith (i.e. the Prophet's daily actions and sayings)

All entrepreneurs including Muslim entrepreneurs meet increasingly competitive business competition. The companies must have competent resources to improve the quality and quality of business. Human resources (HR) become a driving factor in company activities. HR has the creativity and expertise to make the company achieve its goals. In addition to competition between companies, HR is also one that will face competition in business. One factor to causes HR competes and can help companies to achieve their goals is good performance from leadership of organization (Purnama and Sesilya, 2016).

Neal and Biberman (2004) stated the importance to practice spirituality in organizations. They further stated that although there are most powerful variables related to the effectiveness of a person, team or organization, aspects of spirituality have a positive effect on one's work life to produce a good change in leadership style and job satisfaction. Fry (2003) showed a relationship between spirituality and job satisfaction. Tischler et al. (2002) said that people, who are healthier, more satisfied, and more productive in their work lives, are people who have a higher level of spirituality (Neck and Milliman, 1994).

Strack (2001) found a positive correlation between health conditions and effective leadership practices and performance felt by managers themselves and their level of spirituality. McCormick (1994) stated that managers' behavior in workplace is affected by their behavior in religion and spirituality. Spirituality is very important for human experience (Mitroff et. al., 1999).

The different view comes from Dean (2004) that spirituality did not have relation with individual and organizational performance. Mitroff (2003) and Krishnakumar and Neck (2002) also found that spirituality was not useful for employees.

Research by Farooqui and Asha (2014) showed that employees will like their work in organization when they feel valued by company management by giving things that can increase their job satisfaction. When someone feels 
satisfaction in their work, then he will try harder in work to improve the quality of its performance.

Although some of above studies conclude that spirituality affects on managers effectiveness, but studies that discuss this with knowledge are very limited, literature on welfare concepts offered by Islam is also still not widely found (Ali and Owaihan, 2008), and there are gaps in form of differences research results for the effects of spirituality on employee performance. Many researchers found conventional concepts that are practiced in Islamic organizations, but it is very rare to find empirical research with Islamic concepts in Islamic organizations. This is very important to facilitate a Muslim businessman to practice Islamic values in their daily lives. Therefore, existence of this research is expected to become a reference.

\section{Problem Formulation}

1. Does spirituality affects on Islamic job satisfaction?

2. Does spirituality affects on Islamic performance?

3. Does Islamic job satisfaction affects on Islamic performance?

4. Does spirituality affect on Islamic performance mediated by Islamic job satisfaction?

\section{Research purposes}

This study aims to build a theoretical model about the effect of spirituality on Islamic job satisfaction and Islamic performance, and specifically this research aims to examine empirically about:

1) the effect of spirituality on Islamic job satisfaction,

2) the effect of spirituality on Islamic performance,

3) the effect of Islamic job satisfaction on Islamic performance, and

4) the effect of spirituality on Islamic performance mediated by Islamic job satisfaction.

\section{LITERATURE REVIEW}

\section{Definition of Spirituality}

Spirituality refers to beliefs and practices based on confidence that there is a non-physical (transcendent) dimension in life. Spirituality describes the relationship between humans and God and various virtues from that relationship. These virtues are believed to become tangible to achieve principles in life and goodness in life.

Tischler (2002) said that spirituality is similar or in a way, related to certain emotions or behaviors and attitudes of individual. Being a spiritual person means being opened, giving, and loving. Fernando (2006) said that spirituality can also about feelings of purpose, meaning, and relationship feelings with others.

Islamic spirituality is a religious attitude within a person who encourages him to behave in accordance with the observance of religion. Indicators of Islamic spirituality are based on Zandi (2015), namely belief (monotheism), ritual worship and the last is repentance.

\section{Definition of Islamic Job Satisfaction}

Job satisfaction from an Islamic perspective is the calm condition obtained by employees before, during and after work, based on belief that work is worship in order to achieve the pleasure of God (Sharifah Hayaati, 2010 in Saadiah, 2014). The indicator of Islamic job satisfaction is based on elements of human creation from Koran by referring to the interpretation of events by al-Ghazali based on four things. First is ruhiyyah job satisfaction, it refers to the satisfaction supported by intrinsic satisfaction of a Muslim when the work done to achieve the pleasure of Allah and in order to get closer (taqarrub) to Allah. Second is intellectual work satisfaction ('Aqliyyah), it refers to the happiness that employees get new knowledge in their work. Third is social work satisfaction (Nafsiyyah). A social work satisfaction at work was a pleasure obtained by employees when they got to know each other. Material satisfaction (jasadiyyah) is the happiness felt by employees when getting salary payments on time. Abdullah bin Umar stated that Messenger of Allah said "Give a worker a wage before his sweat dries." (Narrated by Ibnu Majah, Shahih)

\section{Definition of Islamic Performance}

Abi Abdillah (Zubair) bin Awwam ra, stated that the Messenger of Allah said: "Actually, one of you brings his ropes and goes to the hill to look for firewood on his back to be sold to meet his needs, it is better than begging others, whether they give or not ". (Bukhari HR, no. 1471).

Performance is a real behavior displayed by everyone. The work performance is produced by employees in accordance with role of company. Employee performance is a very important thing in company's efforts to achieve its goals, as the word of God in QS. Al Isra' verse 84 " Say: Each does according to his disposition. Your Lord knows best who is better guided in the way."

Islamic performance in this research is a total collection of work achievements in Muslim workers, including the accuracy and speed of work, quality of work and desire to serve customers and payment of zakat obligations. The indicator is based on Hakim's research (2012) that a Muslim's performance was based on Qur'an and Hadith, 
namely 1) Work Achievement was an entrepreneur completing work optimally according to company standards;

2) Speed and accuracy in working mean entrepreneur complete the tasks on time and using the time only for work;

3) The intention to serve others sincerely, entrepreneurs prioritize sincerity to serve customers; 4) Quality of Work, that is work efficiently and effectively with regard to the attitude of professionalism of an entrepreneur and 5) Zakat payment, entrepreneur always paying zakat from his income.

\section{RESEARCH METHODS}

\section{Research Design and Data Analysis}

This is explanatory research type. This research type aims to analyze the relationships between one variable with another variable or how a variable affects other variables. Based on these explanations it can be seen that this research is intended to answer the formulated problems, based on objectives and to test the hypothesis. Based analysis approach, this research uses a quantitative approach. The quantitative aspects of this research were calculated by Smart-PLS and Sobel methods.

\section{Population and Sample}

The population were all members of Indonesian Muslim Entrepreneurs Community in Korwil Malang. The sample used in this study is based on formula:

$$
\begin{aligned}
& \mathrm{n}=\mathrm{N} /(1+\mathrm{N} \llbracket(\propto) \rrbracket \wedge(2)) \\
& \mathrm{n}=260 /(1+260 \llbracket(0.05) \rrbracket \wedge(2)) \\
& \mathrm{n}=260 / 1.65 \mathrm{n}=157.57
\end{aligned}
$$

The sample in this study was 158 members of KPMI Korwil Malang. The samples are selected random sampling techniques because the population was quite homogeneous.

\section{Research Instruments and Measurement of Research Variables}

The questionnaire was developed using a Likert scale with a range of values from 1 (strongly disagree) to 5 (strongly agree). The indicator of spirituality variable is 13 item questions from Zandi, et al (2015). The indicator of Islamic job satisfaction variable is 5 question items from Saadiah (2014). The last indicator of Islamic performance is 9 item questions from Judge (2012).

\section{Conceptual framework}

Figure 1 shows the Conceptual Framework of this research.

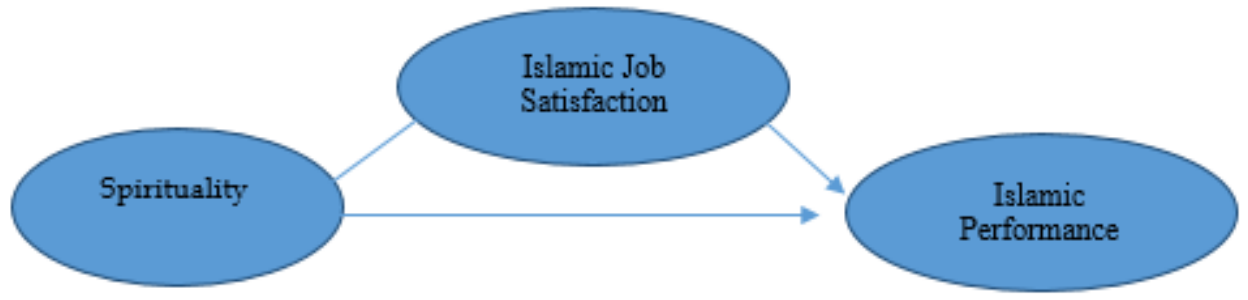

Figure 1. Conceptual Framework

\section{Research Hypothesis}

Based on above conceptual framework, the research hypotheses can be stated below.

H1. Spirituality affect on Islamic Job Satisfaction (Neal and Biberman, 2004 and Fry, 2003).

H2. Spirituality affect on Islamic Performance (Strack, 2001 and Tischler, 2002).

H3. Islamic Job Satisfaction affect on Islamic Performance (Farooqui and Asha, 2014).

H4. Islamic Job Satisfaction Mediate the Effect of Spirituality on Islamic Performance (Neal and Biberman, 2004; Fry, 2003, Strack 2001 and Tischler, 2002).

\section{Data Collection Methods and Sources}

This research uses two data sources below.

1. Primary data, i.e. data obtained from filling out questionnaires by KPMI members in Korwil Malang

2. Secondary data, namely data obtained from other sources that support research. Secondary data were obtained from other research literatures, such as books, journals, articles / papers, and entrepreneurial profiles from internet.

The primary data is collected by distributing questionnaires to members of KPMI Korwil Malang to get empirical data related to the proposed hypothesis. 
Data Analysis Results

Testing the Model Measurement (Outer Model)

Table 1 shows the results of model measurement testing.

Table 1. Extract variance leverage (AVE)

\begin{tabular}{|l|c|c|c|}
\hline & (AVE) & Composite Reliability & Cronbachs Alpha \\
\hline Islamic Job Satisfaction & 0.705 & 0.905 & 0.859 \\
\hline Islamic Performance & 0.851 & 0.966 & 0.956 \\
\hline Spirituality & 0.877 & 0.955 & 0.931 \\
\hline
\end{tabular}

Source: Primary Data processed, 2020

Table 1 shows the AVE value for each construct is greater than 0.5. It means the constructs of Islamic Job Satisfaction, Islamic Performance, and Spirituality are good model. All constructs in estimated model meet the discriminant validity criteria.

Composite reliability is good if the value is above 0.70 . Table 1 shows that Composite reliability value for Islamic Job Satisfaction variable is 0.905 , Islamic Performance is 0.966 , and Spirituality is 0.955 . The Composite reliability value three constructs in the model are greater than 0.70 . It means the measurement models or outer models with reflexive indicators have a very high level of validation. The validity of an indicator can be known from the loading value. The explorative research need the value of 0.5 to 0.6 . Thus it can be said that indicators of Islamic Job Satisfaction, Islamic Performance, and Spirituality, really reinforce each other or can measure their latent variables. The model in this study has fulfilled composite reliability.

Construct reliability is good if the Cronbach alpha value is above 0.70 . Table 1 shows the alpha cronbach for Islamic job satisfaction variable is 0.859 , Islamic Performance is 0.956 , and Spirituality is 0.931 . The Cronbach's alpha value of three constructs in the model are greater than 0.70 . It can be said that Islamic Job Satisfaction, Islamic Performance, and Spirituality variables have a high construct reliability that close to 1 , this level of reliability that is classified as very strong. Therefore, that model in this study meets the Construct reliability.

\section{Structural Model Testing (Inner Model)}

The model evaluation uses R-square $\left(\mathrm{R}^{2}\right)$ for dependent construct. The R-square value reflects the predictive power of whole model with a limit on R-square value greater than 0.10 or greater than 10 percent (or goodness-fit of model). Table 2 shows PLS analysis results for the coefficient of determination (R-square).

Table 2. R-square Values of First Model

\begin{tabular}{|l|c|}
\hline \multicolumn{1}{|c|}{ Construct } & R-Square \\
\hline Islamic Job Satisfaction & 0.182 \\
\hline Islamic Performance & 0.462 \\
\hline Spirituality & \\
\hline
\end{tabular}

\section{Source: Primary Data processed, 2020}

Table 2 shows that R-square for Islamic Job Satisfaction is 0.182; it means that Islamic Job Satisfaction is affected by Spirituality by $18.2 \%$. R-square value for Islamic Performance variable is 0.462 ; it means that Islamic Performance is affected by Islamic Job Satisfaction and Spirituality by $46.2 \%$.

Goodness of fit in PLS can be known from Q2 value. The Q2 value has same meaning with coefficient of determination (R-square / R2) in regression analysis. Higher $\mathrm{R}^{2}$ means data more suitable to model. A Q-Square value greater than zero indicates that model has predictive relevance, while a Q-Square value less than 0 (zero) indicates that model has less predictive relevance. Table 2 shows the Q2 value as follows:

Value of $\mathrm{Q} 2=\mathrm{Q}^{2}=1-(1-\mathrm{R} 21)(1-\mathrm{R} 22)(1-\mathrm{R} 23) \ldots(1-\mathrm{R} 2 \mathrm{n})$

$$
\begin{aligned}
& =1-(1-0.182)(1-0.462) \\
& =1-0.4398=0.560=56.0 \%
\end{aligned}
$$

The R-square value from overall model equation is $56.0 \%$, within high category. It means that structural model has a high predictive relevance, model is better and is worthy to be used in predictions.

\section{Hypothesis test}

The results of path analysis with PLS can be shown in figure 2. 


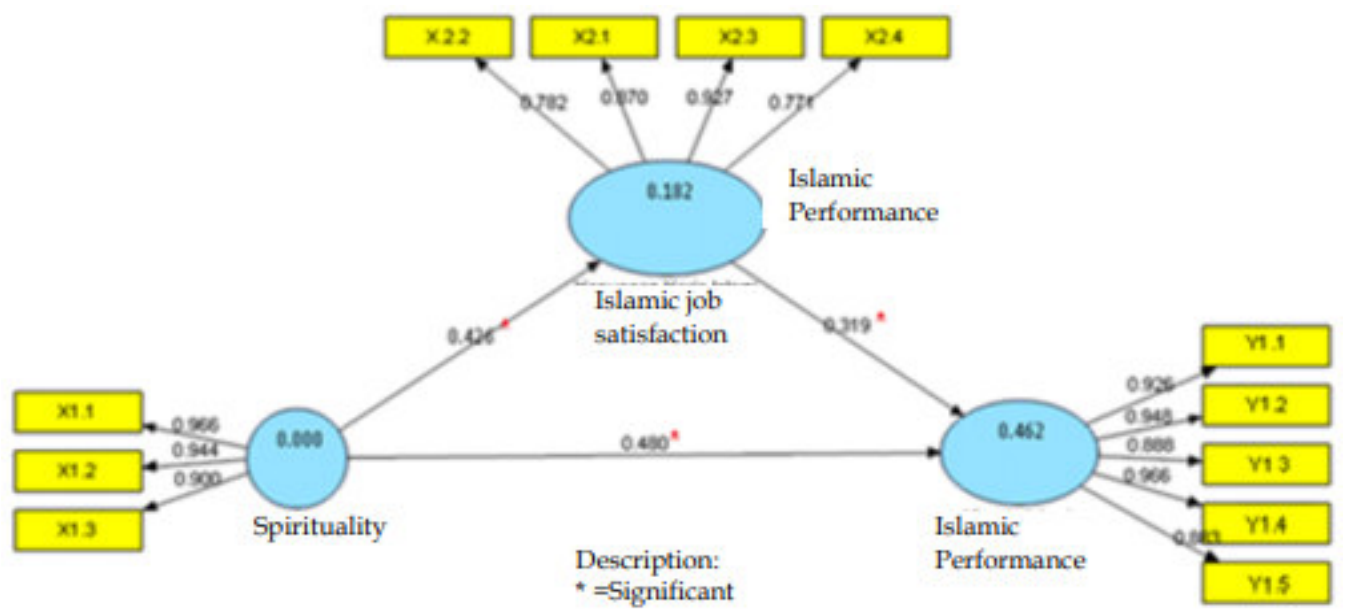

Figure 2. Path analysis results

Hypothesis testing and relationship between variables can be seen from results of path coefficient on model. Table 3 shows the results of path coefficient for inner model.

Table 3. Path coefficient results

\begin{tabular}{|c|c|c|c|}
\hline & STDEV & STERR & T Statistics \\
\hline Islamic job satisfaction $\rightarrow$ Islamic performance & 0.061 & 0.061 & 5.209 \\
\hline Spirituality $\rightarrow$ Islamic job satisfaction & 0.087 & 0.087 & 4.891 \\
\hline Spirituality $\rightarrow$ Islamic performance & 0.067 & 0.067 & 7.173 \\
\hline
\end{tabular}

\section{Source: Primary Data processed, 2020}

Table 3 shows the inner model estimation results for direct effect of Islamic Job Satisfaction on Islamic Performance has a t-statistic value of 5.209, where the value is greater than 1,975 for a two-way test with an error level $\alpha=5 \%$, this shows the direct effect of Islamic Job Satisfaction on performance Islam is significant. The effect is positive with a path coefficient of 0.319 ; it means that better Islamic job satisfaction will increase Islamic performance. And vice versa, lower Islamic job satisfaction will decrease the Islamic performance.

The inner model estimation results for the direct effect of Spirituality on Islamic Job Satisfaction show a tstatistic value of 4.891 . The value is greater than 1,975 for a two-way test with a level of error $\alpha=5 \%$. It shows that the direct effect of spirituality on Islamic Job Satisfaction is significant. The effect is positive with a path coefficient of 0.426 , it means that better spirituality will increase Islamic job satisfaction will also increase. And vice versa, less good spirituality, Islamic job satisfaction will also decrease.

The inner model estimation results for the direct effect of Spirituality on Islamic Performance show a tstatistic value of 7.173. The value is greater than 1.975 for a two-way test with an error level $\alpha=5 \%$, it shows the direct effect of spirituality on Islamic performance is significant. The effect is positive with a path coefficient of 0.480 , it means that better spirituality will increase the Islamic performance. And vice versa, lower spirituality will decrease the Islamic performance.

The indirect effect of some exogenous variables on endogenous is calculated by sobel test. The indirect effect can be determined by multiplying the path coefficient value on each variable.

The path coefficient value for indirect effect of Spirituality on Islamic Performance through Islamic job satisfaction of 0.136 shows a t-value of 3.531 which is above $\pm 1.975(5 \%)$, the Ho is rejected. It can be concluded that indirect effect between Spirituality on Islamic Performance through Islamic job satisfaction is significant. In other words, magnitude effect of Spirituality caused by Islamic job satisfaction on Islamic Performance is positive, it means that greater Spirituality caused by Islamic work satisfaction will increase the Islamic Performance, and vice versa.

\section{CONCLUSIONS AND RECOMMENDATIONS}

Based on study results, the conclusions can be stated below.

1. The implementation of spirituality by Muslim entrepreneurs can increase Islamic job satisfaction.

2. The implementation of spirituality by Muslim entrepreneurs can improve Islamic performance.

3. High Islamic job satisfaction can improve Islamic performance.

4. The implementation of spirituality value can increase Islamic job satisfaction and this can encourage an increase in Islamic performance.

Based on above conclusion, the suggestions can be stated below.

1. Muslim entrepreneurs should increase monotheism in themselves to put God as the only place of all goals, including in work and only to Allah asking for help for all problems. 
2. Muslim entrepreneurs should increase their worship to Allah and invite their subordinates to also increase worship.

3. Muslim entrepreneurs should treat subordinates well, receive the suggestions and criticisms and not have to feel ashamed to apologize if something goes wrong.

4. Future researcher can deepen the scope of investigation by adding the qualitative methods, namely in depth interviews.

\section{REFERENCES}

Al-Qaradawi, Y. 2001. The Role of Zakat in MitigatingEconomic Challenges. Cairo: Dar-Shorouk.

Beekun Rafik I. 2012. Character centered leadership: Muhammad (p) as an ethical role model for CEOs.Journal of Management Development, Volume 31, Issues 10, pages $1003-1020$.

Bin Shmailan, Abdulwahab S.The Relationship Between Job Satisfaction, Job Performance and Employee Engagement: An Explorative Study. 2016. Business Management and Economics. Vol.4 (1), pp. 1-8, January

Dean, K.L. 2004. Systems thinking's challenge to research in spirituality and religion at work: An interview with IanMitroff. Journal of Organizational Change Management, 17 (1): 11-25.

Fanggidae, E, Rolland., Yuyus Suryana., Nuri Effendi and Hilmiana. 2016. Effect OfA Spirituality Workplace on Organizational Commitment and Job Satisfaction. Procedia Social and Behavioral Sciences. 639 - 646.

Farooqui, Ms. Safia, Asha Nagendra. 2014. The Impact of Person Organization Fit on Job Satisfaction and Performance of the Employees. Procedia Economics and Finance,volume11, pages122 - 129. Elseiver.

Fernando, M. and B. Jackson 2006. The influence of religion-based workplace spirituality on business leaders' decision-making: an inter-faith study. The Journal of Management and Organization 12(1): 23-39.

Fry, L.W. 2003. Toward a theory of spiritual leadership. The Leadership Quarterly, 14(6): 693-727

Garg, Naval., B.K. Punia., Anuradha Jain. 2019. Workplace Spirituality and Job Satisfaction: Exploring Mediating Effect of Organization Citizenship Behaviour.

Khaliq Ahmad dan Rodrigue Fontaine. 2011. Islamic Leadership At The International Isamic University Malaysia.International Journal of Economics, Management and Accounting,volume19, no. 2 (2011): pages 121-35.

Khaliq Ahmad, Ogunsola O.K. 2011. Anempirical assessment of Islamic leadership principles. International Journal of Commerce and Management, Volume 21, Issues 3, pages $291-318$.

Kazmi, A. 2004. A preliminary enquiry into the paradigmatic differences between the conventional and islamic approaches to management studies. Malaysia: IIUM, Unpublished Paper.

Khraim, H.S., A.S. Khraim, F.M. Al-Kaidah and D.R. Al-Qurashi. 2011. Jordanian consumer's evaluation of retail store attributes: The influence of consumer religiosity. International Journal of Marketing Studies, 3(4): 105.

Kouzes, J. and B. Posner. 2012. The leadership challenge: How to make extraordinary things happen in organizations: Jossey-Bass, 204.

Krishnakumar, S., \& Neck, C.P. 2002. The "what," "why" and"how" of spirituality in the workplace. Journal of ManagerialPsychology, 17 (3): 153-164

McCormick, D.W. 1994. Spirituality and management. Journal of Managerial Psychology, 9(6): 5-8.

Mitroff, I.I. 2003. Do not promote religion under the guise of spirituality. Organization, 10 (2): 375-382.

Farooqui, Ms. Safia, Asha Nagendra. 2014. The Impact of Person Organization Fit on Job Satisfaction and Performance of the Employees. Procedia Economics and Finance, volume11, pages122 - 129. Elseiver.

Neck, Cristopher and John F. 1994. Milliman.Thought Self-Leadership: Finding Spiritual Fulfilment in Organizational Life. Journal of Managerial Psychology

Neal, J. and J. Biberman. 2004. Research that matters: Helping organizations integrate spiritual values andpractices. Journal of Organizational Change Management, 17(1): 7-10

Shibani Belwalkar, Veena Vohra, Ashish Pandey.2018.The Relationship between Workplace Spirituality, Job Satisfaction and Organizational Citizenship Behaviors - An Empirical Study. Social Responsibility Journal. Emerald Insight.

Strack , G., Che and M. Fottler. 2002. Spirituality and effective leadership in healthcare: Is there a connection Frontiers of Health Services Management, 18(4): 3.

Strack, J.G.2001. The relationship of healthcare managers' spirituality to their self-perceived effectiveleadership practices (Doctoral Dissertation, Medical University of South Carolina).

Tischler, L., J. Biberman and R. McKeage. 2002. Linking emotional intelligence, spirituality and workplaceperformance: Definitions, models and ideas for research. Journal of Managerial Psychology, 17(3): 203-218.

Zandi, dkk. 2015. Spirituality and Leaders Effectiveness: an Islamic Perspective. Asian and Financial Economic Review 5 (1): 155-166. 